\title{
DMP VIII: Palaeohydrology and palaeoenvironment
}

\author{
Nicholas Drake, ${ }^{1}$ Kevin White, ${ }^{2}$ Mustapha Salem, ${ }^{3}$ Simon Armitage, ${ }^{4}$ Ahmed El-Hawat, ${ }^{5}$ Jan Francke, ${ }^{1}$ \\ Mark Hounslow, ${ }^{6}$ Adrian Parker ${ }^{7}$
}

\begin{abstract}
The January 2009 fieldwork season conducted geomorphological and palaeoenviromental surveys in as yet unexplored parts of the Lake Megafazzan Basin, as well as continuing research in the Wadi al-Hayat and Ubari Sand Sea. Lake Megafazzan sediments were investigated at two sites on the eastern margin of the basin. At the first site, east of Tamessah, $24 \mathrm{~m}$ of stratigraphy was investigated and found to consist of a lacustrine carbonate unit at the base progressing into a fluvial unit and then an upper carbonate unit. The sediments were sampled for magnetostratigraphy and cosmogenic nucleide dating in order to determine their age. Similar studies were undertaken in the vicinity of the Arial Agricultural Project, where $31 \mathrm{~m}$ of section were logged and sampled. Here the sediments were quite different, being composed of a deltaic sequence consisting of stacked channels and palaeosols, thought to represent the outflow delta of the palaeolake. Many new Holocene lake sediment deposits were discovered and sampled in the Wadi al-Hayat and the Ubari Sand Sea, including a $5 \mathrm{~m}$ section through Jarma Playa that appears to record the last arid-humid cycle. Lake Gabr 'Awn and the moat round Old Jarma were cored in order to gather a detailed picture of recent palaeoenvironmental change. Finally, we implemented a pilot geophysical survey to test the ability of state-of-the-art Ground Penetrating Radar (UltraGPR) technology for detecting and mapping buried palaeolake sediments under the dunes of the Ubari Sand Sea. The UltraGPR was found to be very effective, detecting palaeolake sediments as much as $60 \mathrm{~m}$ beneath the surface. Preliminary results suggest such sediments underlie much of the region.
\end{abstract}

\section{Introduction}

The palaeohydrology and palaeoenvironment sub-project of the Desert Migrations Project (DMP) focuses on palaeoclimate and hydrological change during the Quaternary in order to further our understanding of the chronology of arid/humid cycles, the nature of the contemporary palaeoenvironment and the processes that caused them. By integrating these results with those of the Pleistocene, Holocene and Garamantian archaeology (DMP sub-projects V and VI) we hope to understand the relationships between palaeoclimate-change archaeology and past human migrations in the Fazzan.

Research consisted of three thematic sub-projects. First, logging and dating the stratigraphy of sediments from Lake Megafazzan (the al-Mahruqah Formation). This fieldwork concentrated on evaluation of sediments exposed on the western margin of the basin between the Arial Agricultural Project and al-Haruj al-Aswad (Fig. 1). This work has enabled us to determine the palaeogeography of the eastern margin of Lake Megafazzan from the horizontal changes in sedimentary facies; follow-up laboratory analysis will provide new insights into the palaeoenvironments associated with this giant lake and further constrain the timing of humid climate episodes.

The second sub-project involved studying the younger palaeolake sediments in the Jarma region deposited by smaller Holocene palaeolakes (Fig. 1). This involved investigating outcrops, as well as coring of contemporary and Holocene lake sediments in the Ubari Sand Sea. The results of laboratory analysis of these samples and cores will enable us to reconstruct the environmental changes occurring in the region during the last 10,000 years.

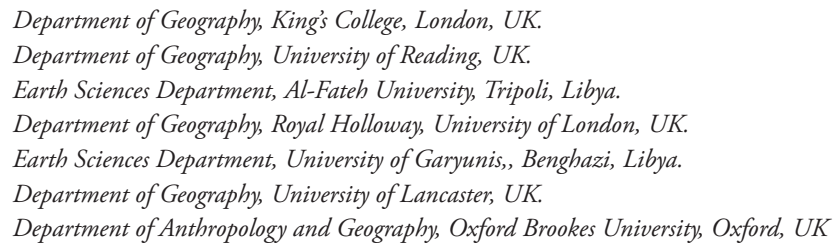


Finally, ground penetrating radar surveys using state-of-the-art radar technology were implemented to characterise the subsurface stratigraphy surrounding palaeolakes in the Ubari Sand Sea; the results of this work will establish the true extent of palaeolake sediments under the sand sea. Initial analyses of the data suggest the lake sediments extend under the contemporary dunes.

These different subprojects are discussed in turn below.

\section{The al-Mahruqah Formation}

The aim of this part of the fieldwork is to extend our understanding of the stratigraphy, palaeoenvironment and age of lacustrine sediments of the Megafazzan Basin. In order to fulfil this aim, sites were selected by analysis of geological maps, satellite imagery, digital elevation models and previous fieldwork. This will allow us to compare the stratigraphy of all these sections with those of the other sites that we have studied in the Megafazzan Basin in previous years (Lahr et al. 2008; Mattingly et al. 2007) in order to build up a regional understanding of the stratigraphy.

\section{Al-Mahruqah Formation Methods}

\section{Geochronology}

The stratigraphy of exposed sections was logged and selected samples collected for the following analysis. The overall aim of the geochronology is to improve our understanding of the age of the various Lake Megafazzan sediments. To this end we have applied magnetostratigraphy, cosmogenic nuclide dating and optically stimulated luminescence dating.

\section{Magnetostratigraphy}

Magnetic dating is primarily focussed on evaluating the age of sediment successions older than c. $600 \mathrm{ka}$. The method relies on determining the pattern of the Earth's magnetic field polarity changes (changes from normal to reverse polarity configuration of the Earth's magnetic field, recorded by the sediments i.e. the magnetostratigraphy) through sediment successions and matching this normal/reverse 'bar-code' against the magnetic polarity timescale to determine age. Hence, it is necessary to utilise

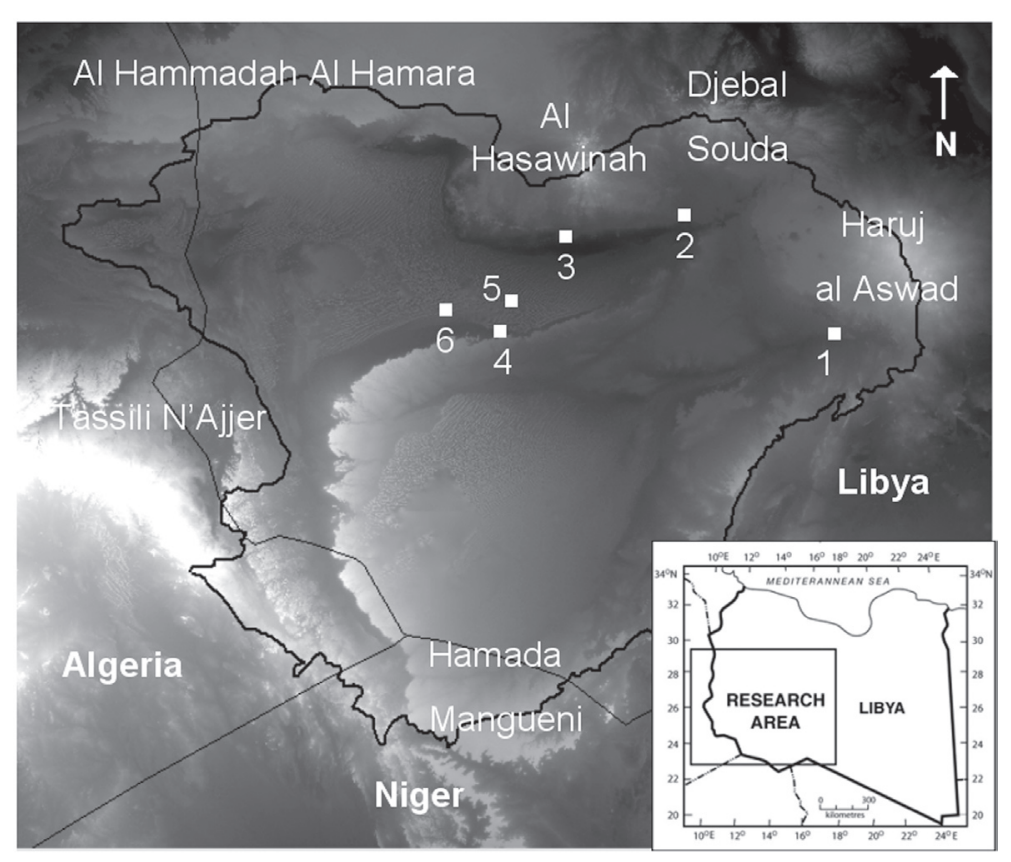

Figure 1. Digital elevation model of the Fazzan region with the catchment boundary of the Fazzan Basin marked in black. The sites that were investigated are numbered: (1) east of Tamessah, (2) Arial Agricultural Project, (3) the Brak type section, (4) Jarma Playa in Wadi al-Hayat, (5) Lake Gabr 'Awn in the southern Ubari Sand Sea, (6) Turquoise Lake in the southern Ubari Sand Sea. this method in the thickest and most continuous sections available, along with a high sampling density, to evaluate properly the pattern of magnetic polarity changes.

Cosmogenic Nuclide Dating

Cosmogenic nuclide burial dating utilises the radioactive decay of ${ }^{26} \mathrm{Al}$ and ${ }^{10} \mathrm{Be}$ in quartz. When sediments are near the surface, cosmic rays interact with quartz crystals and create ${ }^{26} \mathrm{Al}$ and ${ }^{10} \mathrm{Be}$ with a well known ratio of their production rates within the mineral grains. These isotopes have different halflives, with that of ${ }^{26} \mathrm{Al}$ being about twice that of ${ }^{10} \mathrm{Be}$, and this forms the basis of the burial dating technique. Once sediments are buried, the isotopes are no longer being created and the difference between the concentrations of the two isotopes 
will start to increase. Concentrations will continue to diverge with burial age, thus the difference in the two isotope concentrations can be used to determine the date the sediments were buried and has an age limit of about 5 million years.

\section{Optically Stimulated Luminescence (OSL) Dating}

OSL dating is a geochronological technique which allows the time elapsed since a mineral grain was last exposed to sunlight, or heated, to be estimated. In the case of sub-aerial sediments this time equates to the age of deposition. The method is used to date quartz deposition and has an age range typically of between 0 and $200 \mathrm{ka}$.

\section{Thin-Section analysis}

Eighty samples were collected from the al-Mahruqah Formation exposures for thin-section analysis. It is expected that these samples will reveal a considerable amount of information on the petrology and sedimentology of the lacustrine sediments.

\section{Al-Mahruqah Formation Results}

\section{Tamessah}

Twenty-four metres thickness of al-Mahruqah Formation stratigraphy was logged in detail east of Tamessah (Fig. 1; site 1). First we established a type section at $26^{\circ} 30.360^{\prime} \mathrm{N} 16^{\circ} 33.000^{\prime} \mathrm{E}$ where there was exceptional exposure over a large area. The section starts with a stromatolitic unit near the base, progressing into a lower clastic and upper carbonate unit, both exhibiting multiple sedimentary cycles. The clastic unit showed evidence of channel deposition, with rapid facies variations from channels to rootleted mudstones, sometimes capped by palaeosols. The channels indicate runoff flowing to the south-south-east. Throughout this section, 48 magnetostratigraphic samples were collected (one sample every $50 \mathrm{~cm}$ down the section). In addition, five samples of coarse sands were collected for cosmogenic nuclide dating, to develop an age model for the measured sections. Selected samples will be made into thin sections and analysed for phytoliths in order to gain further insights into the environment at the time of sediment deposition.

We explored the outcrops to the east and north-east of this type section and found a consistent stratigraphy over an area of $20 \mathrm{~km}^{2}$. As part of this exercise we measured and reinterpreted the geological map type section in the Haruj al-Abyad map sheet (Peregi 2003) and found $34 \mathrm{~m}$ of stratigraphy from the top of the basement (Cretaceous sandstone) to the capping of the limestone/calcrete breccia. This stratigraphy closely conformed to our type section. We also evaluated a further six sections with a view to developing a threedimensional model and establishing the geometry and facies change of sand units in relationship to the carbonate units above and below. The results of this study are still being processed and interpreted; however, initial results suggest that the above-mentioned sedimentary successions are more proximal in the north and distal in the south, consistent with sedimentation on the margins of a large lake in the

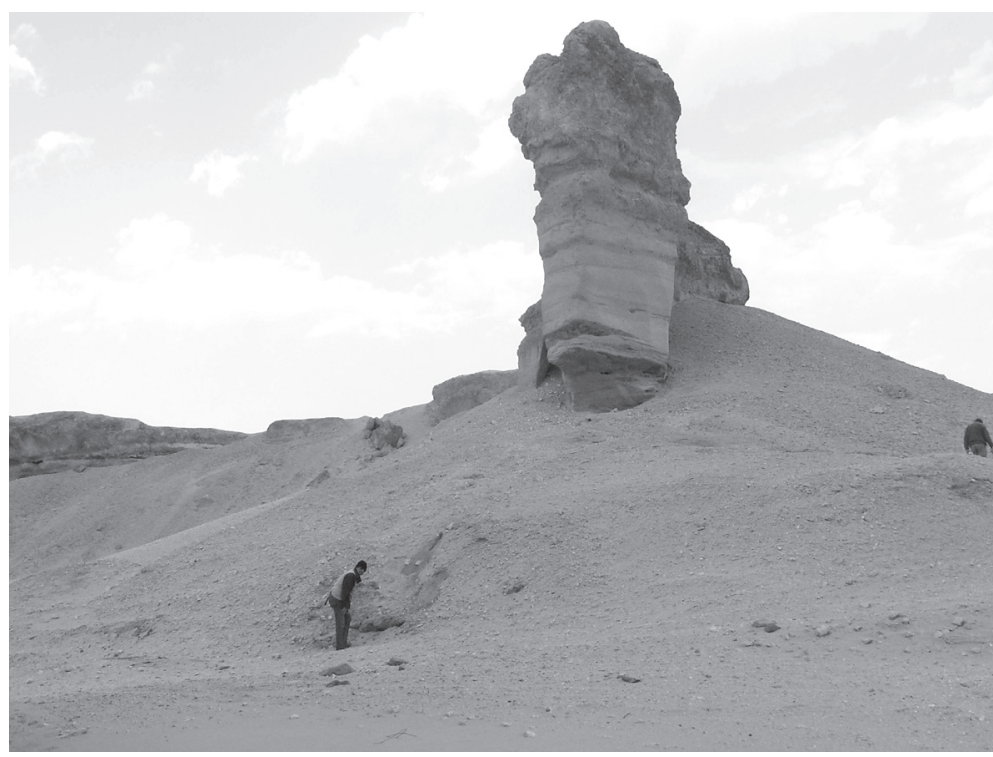

Figure 2. Lake Megafazzan palaeodeltaic sediment sequence exposed in the region of the the Arial Agricultrual Project at the eastern end of Wadi Shati (see Fig. I for location). 


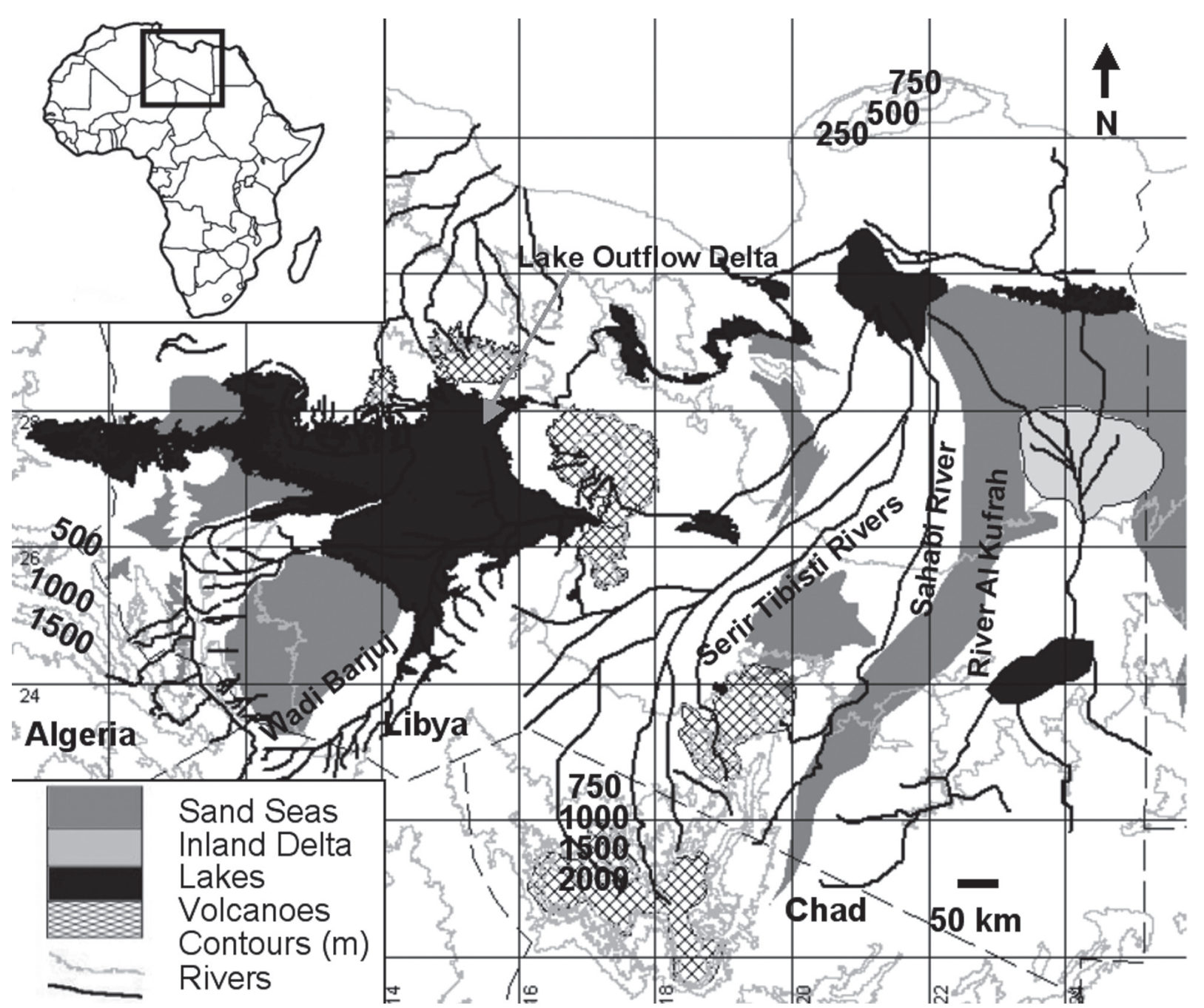

Figure 3. Map showing the probable river, lake and sand sea systems in Libya during humid periods in the Pleistocene (after Drake et al. 2008). Lake Megafazzan overspill waters would have overflowed, filling up and overspilling a series of basins, forming a chain of lakes that ultimately outflowed into the Mediterranean Sea.

Fazzan basin. A $290 \mathrm{~km}$-long exposure of sediments was examined between Tamessah and the SabahFuqha road; these showed strong similarities to the above-mentioned sediments, supporting the view that the sediments were deposited by a very large lake.

Arial Agricultural Project

Similar studies were undertaken in the vicinity of the Arial Agricultural Project (Fig. 1, site 2), where $31 \mathrm{~m}$ of section were logged (Fig. 2). Here 59 magnetostratigraphic samples and five cosmogenic nuclide samples were collected to establish a chronology for the section. The stratigraphy is divided into two units, a lower clastic unit and a higher calcareous upper unit. In this sense it shows similarities to the Tamessah sections, but the facies are significantly different. They consist of a prograding coarsening upwards deltaic sequence composed of stacked channels and palaeosols. The whole sequence is extensively rootleted, destroying most primary sedimentary structure. The palaeosols contain sand, silt and organic matter, the latter more abundant in the upper units. The top of the sequence is composed of several large ( $>5 \mathrm{~m}$ thick) channels that cut through the calcareous sandstones and calcretes that comprise the upper part of the section. These large channel-systems indicate flow to the east. The location of this sedimentary succession on the north-eastern margin of the Fazzan topographic basin, very close to the low point on the catchment rim that Drake et al. (2008) postulated was an outflow point of Lake Megafazzan during high stands (Fig. 3), with evidence of flow towards the east in the direction of the proposed outflow channel complex, suggests that it represents the deposits of an outflow delta of Lake Megafazzan that was active during high stands. 
Brak

Magnetostratigraphic results from previous years (Lahr et al. 2008; Mattingly et al. 2007), though preliminary because sample processing of some sections is still in progress, show numerous units of normal and reversed polarity suggesting that parts of the al-Mahruqah Formation, and possibly all of it, are older than $750 \mathrm{ka}$ when the last reversal occurred. This finding contrasts with those of Thiedig and Geyh (2004) and Thiedig et al. (2000) who applied U/Th dating to the al-Mahruqah Formation and found it to be much younger (c. 200-400 ka). Because we have so far studied different exposures, it is possible that this discrepancy lies in the fact that we are dating different sediments and thus different lake episodes. It was decided to investigate this by applying magnetostratigraphy to the type sections dated by Thiedig et al. (2000) and Thiedig and Geyh (2004). Thus the type section of al-Mahruqah Formation near Brak (Fig. 1, site 3) was revisited for direct comparison with the new localities described above and those visited in previous years. Twenty-two samples were collected for magnetostratigraphic analysis, and one sample was collected for cosmogenic nuclide analysis. Twelve metres of section were logged, consisting of $3.8 \mathrm{~m}$ of mudstone with palaeosols, grading into $1.5 \mathrm{~m}$ of calcareous sandstone with fractures filled with chalky calcrete, overlain by $7.5 \mathrm{~m}$ of massive calcrete.

\section{Holocene Lake Sediments}

A number of Holocene sites with palaeolake sediments that postdate the al-Mahruqah Formation were investigated, all in the vicinity of Jarma. Research involved investigating palaeolake outcrops, as well as coring of contemporary and Holocene lake sediments. At selected sites stratigraphy was logged and samples were collected for OSL dating and analysis of samples for pollen, diatoms, phytoliths, bulk chemistry, magnetic susceptibility and radiocarbon dating in order to develop a chronological record of environmental change over the last 10,000 years.

\section{Palaeolake Sediment Outcrops}

We have extended our knowledge of palaeolake sediment exposures in the Wadi al-Hayat (Fig. 1, site 4) by investigating stratigraphic exposures in wells and trenches dug for urban expansion or waste disposal. Many promising sites were discovered but due to time restrictions only one was studied in detail this year. The rest will be investigated in the next field season. This season we concentrated on logging the stratigraphy and sampling a $5 \mathrm{~m}$-deep trench dug into Jarma Playa near the village of Twesh that appears to have been excavated as part of the installation of a sewage disposal system for the village. The uppermost part of the section consists of of a $10 \mathrm{~cm}$ thick gypsum crust overlying $110 \mathrm{~cm}$ of lacustrine silts containing lenticular gypsum crystals that grew within the groundwater-saturated sediments during the dessication of the lake. The crust contains lenses of archaeological remains, notably Garamantian pottery, ovicaproid bones, slag from glass-making and hearths. Thus it appears that the Jarma Palaeolake had dried up, and the gypsum crust started to form by the Garamantian period (c. $2 \mathrm{ka})$. Furthermore, in places thick gypsum crusts overlie these archaeological deposits, indicating that they continued to develop for some time after the Garamantian period. These results are consistent with the findings of Brooks et al. (2003) and Drake et al. (2004), who found evidence that the lake dried up about 3,000 years ago.

These palaeolake sediments overlie $110 \mathrm{~cm}$ of sand that contains rootlets and carbonate nodules and exhibits green, red and yellow mottling. This is interpreted as a deposit of aeolian sand that experienced pedogenesis during the humid phase that led to the development of the palaeolake. Underlying this was a $70 \mathrm{~cm}$-thick layer of fine sand suggesting continued aridity. This is in turn preceded by a $30 \mathrm{~cm}$ layer of sandy silt cemented by gypsum and halite, followed by $8 \mathrm{~cm}$ of poorly sorted silt with some sand and gypsum cement, that may represent the brief establishment of a saline lake in the basin, perhaps indicating slightly more humid conditions than the preceding period of aeolian activity. The base of the section consists of $>70 \mathrm{~cm}$ of aeolian sands that attest to a return to an arid environment.

In summary, the stratigraphy of the site appears to suggest that a period of aridity and associated aeolian activity was followed by a lacustrine interval that terminated about $3 \mathrm{ka}$ and was followed by 


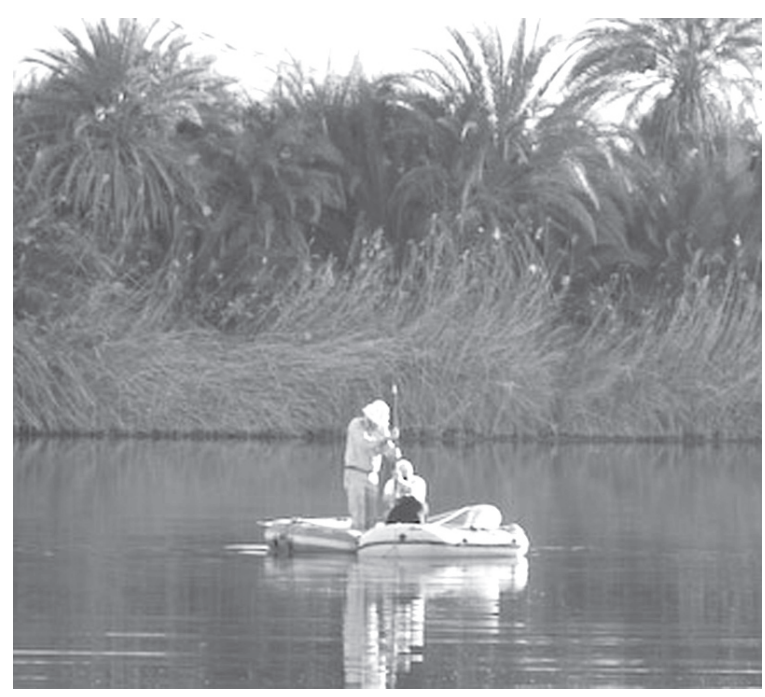

Figure 4. Coring Lake Gabr 'Awn using a Livingstone piston corer system from boats moored in the lake.

the development of a gypsum crust. Four samples were collected for OSL dating to elucidate the timing of these events.

\section{Coring of Contemporary Lakes and Palaeolakes}

The coring programme utilised vibra-corer equipment on land surfaces and a Livingstone piston corer system from boats moored in the lake at Gabr 'Awn (Fig. 1, site 5; Fig. 4). With the vibra-corer we collected $4 \mathrm{~m}$ of sediment from the moat which surrounds Old Jarma (Fig. 1, site 7), going right through the silts and clays deposited in the moat and into the aeolian sands beneath the moat. Analysis of this sediment core (pollen, diatoms, phytoliths, bulk chemistry, magnetic susceptibility and radiocarbon dating) will provide important new evidence concerning the chronology of environmental change during the occupation of the settlement.

The vibra-corer also yielded $1.5 \mathrm{~m}$ of sediment through the highly lithified ancient lake sediments at a site in the Ubari Sand Sea we have termed Turquoise Lake (Fig. 1, site 6; 26 $42.216^{\prime} \mathrm{N}, 12^{\circ} 54.000^{\prime} \mathrm{E}$ ). This core will highlight the succession of sediments produced during lake desiccation, and will also enable us to develop an age model to link these deposits into the regional chronology of lacustrine phases we have developed for the Fazzan. The stratigraphy revealed by the core will also help validate the results of ground penetrating radar surveys, extending the near-surface data obtained from shallow trenches in previous seasons.

The piston corer yielded two cores from the contemporary lake at Gabr 'Awn (Fig. 4): $2 \mathrm{~m}$ of sediment was collected from relatively shallow $(2.5 \mathrm{~m})$ water depth, and $3.5 \mathrm{~m}$ of sediment was collected from deeper $(4.5 \mathrm{~m})$ water depth, using a temporary floating platform of inflatable boats. Analyses of these cores (pollen, diatoms, phytoliths, bulk chemistry, magnetic susceptibility and radiocarbon dating) will provide important new evidence on the chronology of environmental change in the Ubari Sand Sea. We have made contact with environmental scientists at Sabha University who are carrying out long-term monitoring of chemical and biological changes in the contemporary lake, and we hope to combine our palaeoenvironmental data with their contemporary observations in a collaborative research programme.

\section{Long-range ground penetrating radar studies in the Ubari Sand Sea}

A series of geophysical surveys involving a newly-developed type of ground penetrating radar (GPR) instrument were conducted in the Ubari Sand Sea in the area north of Ubari (between sites 4, 5 and 6 in Fig. 1). The primary aim of these studies was to image through the dunes to the underlying sediments in order to evaluate the hypothesis that the al-Mahruqah Formation underlies the dunes, forming a continuous layer of sediments from Brak to Ubari. Although standard GPR had been applied in numerous locations in previous years with limited success, the instrumentation employed during the present field program represented a series of technology advancements which greatly extends the penetration of standard GPR and increases the speed at which the data can be acquired as it can be towed behind a vehicle or pulled by people at walking speed through more complex terrain.

The instrument, known as UltraGPR, is the first to employ real-time sampling technology to maximize the signal-to-noise ratio of the returned signals, enabling far more distant reflections to be recorded than was possible previously. This technology, coupled with a more powerful transmitter and more sensitive receiver has been shown in other sand environments to enable penetration depths of up to $80 \mathrm{~m}$ in arid sand. In addition, the system was designed to be field rugged by eliminating all wires and fibre-optics. 


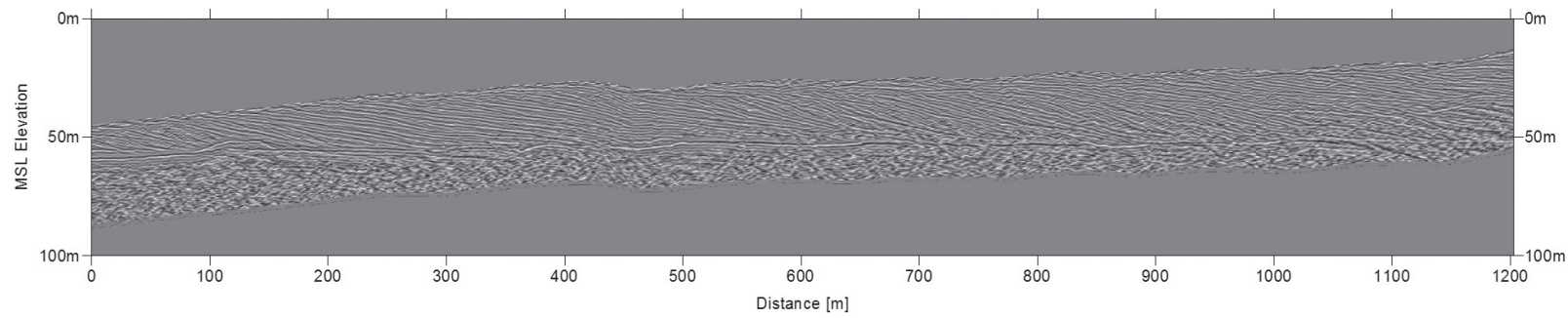

Figure 5. Part of a $6 \mathrm{~km}$ UltraGPR transect between sites 5 and 6 (see Fig. 1 for location).

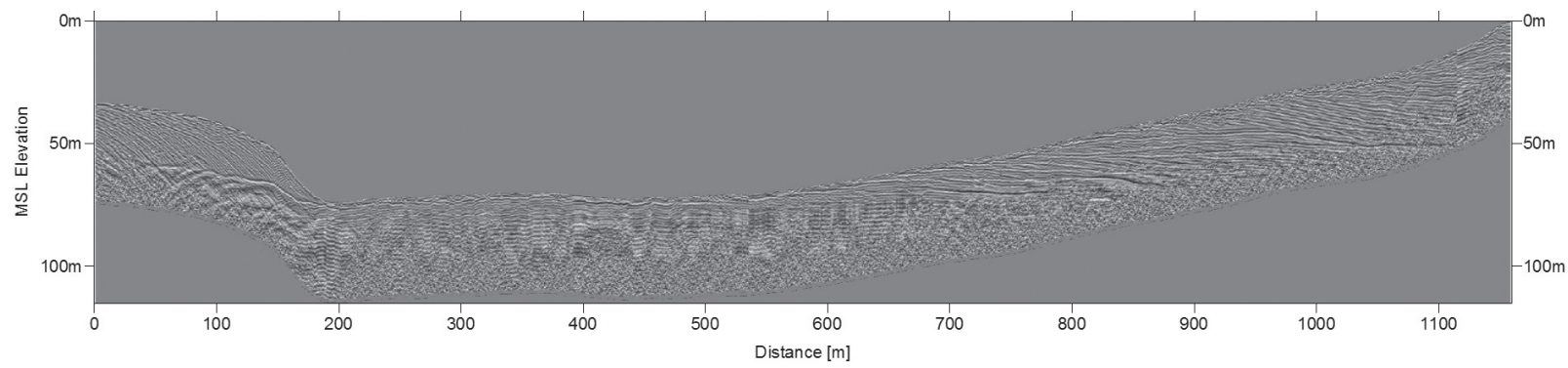

Figure 6. Part of the UltraGPR transect at Turquoise Lake (see Fig. 1, site 6 for location).

Some $5 \mathrm{~km}$ of UltraGPR profiles were acquired at the Lake Gabr 'Awn site. The majority of the radar profiles were attempts to image through dunes, many higher than $100 \mathrm{~m}$. In dry sand, computational predictions suggested that the deep UltraGPR system should have been able to image the base of dunes to depths of up to $80 \mathrm{~m}$. A preliminary examination of the results indicates that the maximum penetration achieved was on the order of 40-50 m. Furthermore, the drop in radar signal amplitude beyond these depths is relatively abrupt, suggesting that these dunes may contain media which is highly absorptive of radar energy. Two radar profiles were acquired across a dried lake bed. The penetration of the radar energy though the lake sediments appears to be less than $8 \mathrm{~m}$. This limited penetration is expected in evaporitic basins, which often include salt-crusts and evaporite minerals in solution. The electrolytes in these minerals significantly increase electrical conductivities, thereby limiting radar penetration, regardless of the GPR technology applied.

Elsewhere in the Ubari Sand Sea, in order to gather as much UltraGPR data as possible, the radar instrumentation was towed behind a vehicle over a series of shallow dunes and dried lake beds. Surveys were conducted over tens of kilometres at speeds approaching $35 \mathrm{~km} / \mathrm{hr}$. Once corrected for topography using the on-board DGPS elevations, a clear-reflecting horizon, interpreted as the palaeolake surface which outcrops at either end of the transect, is evident across the sample part of a $6 \mathrm{~km}$ section shown in Figure 5. This horizon appears to be gently undulating. The radar system was able to penetrate through dunes as high as $57 \mathrm{~m}$ to image the underlying horizon. Radar data acquired across the surface of palaeolake sediments showed minimal penetration, suggesting that they contain highly conductive materials and helping to explain the observation made during previous remote sensing studies of the area, which demonstrated that orbital radar images are useful for mapping these palaeolake surfaces (Charlton and White, 2006; White et al. 2006).

Additional detailed profiles were acquired across Turquoise Lake (Fig. 1; site 6), an interdune palaeolake north of Ubari, to confirm the continuity of a palaeolake surface beneath overlying dunes. Although no significant penetration was achieved when crossing the palaeolake sediment surface, within the dunes a series of foreset beds were clearly imaged to depths of over $30 \mathrm{~m}$ (Fig. 6). Any bedding within the dune structure appears to terminate at the underlying undulating horizon, indicating that this radar reflector is not the groundwater table, and supporting the interpretation that it comprises an extension of the palaeolake surface buried underneath the dunes.

Whilst radar surveying dunes around a palaeolake bed $1 \mathrm{~km}$ south of Sabkha Bani Atayi, an unusual feature was noted on the raw UltraGPR data. In contrast to the horizontal and sub-horizontal bedding typical elsewhere over the dune surface, the anomalous zone exhibited highly chaotic reflections, uncharacteristic of sands. The anomaly appeared to extend beyond $50 \mathrm{~m}$ in depth and was restricted to 
a region of less than $100 \mathrm{~m}$ diameter. In an effort to gather as much data as possible over the anomaly for later 3D analysis, a series of profiles were acquired in a rough grid. Further processing of the data will attempt to identify the nature of these enigmatic targets, but currently we think they are related to the adjacent palaeolake sediments.

\section{Acknowledgements}

We would like to thank the Department of Antiquities for supporting the project, particularly the President Giuma Anag, and the controller of the Fazzan Mohammed Arreda. We are also grateful to the Society for Libyan Studies, Garyunis Research Centre, Remsa and Repsol Oil Co for financial support.

\section{References}

Brooks, N., Drake, N., MacLaren, S. and White, K. 2003. Studies in Geography, Geomorphology, Environment and Climate. In Mattingly, D.J., Dore, J.N. and Wilson, A.I. (eds) The Archaeology of Fazzan Volume I: Synthesis. Society for Libyan Studies, London: 37-74.

Charlton, M.B. and White, K. 2006. Sensitivity of radar backscatter to desert surface roughness. International Journal of Remote Sensing 27: 1641-1659.

Drake, N.A., Wilson, A., Pelling, R., White, K.H., Mattingly, D. and Black, S. 2004. Water Table Decline, Springline Desiccation and the Early Development of Irrigated Agriculture in the Wādī al-Ajāl, Libyan Fazzan. Libyan Studies 35: 95-112.

Drake, N.A., El-Hawat, A.S., Turner, P., Armitage, S.J., Salem, M.J., White, K.H. and McLaren, S. 2008. Palaeohydrology of the Fazzan Basin and Surrounding Regions: the Last 7 Million Years. Palaeogeography, Palaeoclimatology, Palaeoecology, 263: 131-145.

Lahr, M.M., Armitage, S., Barton, H., Crivellaro, F., Drake, N., Foley, R., Maher, L., Mattingly, D., Salem, M., Stock, J. and White, K. 2008. DMP III: Pleistocene and Holocene palaeonvironments and prehistoric occupation of Fazzan, Libyan Sahara. Libyan Studies 39: 263-294.

Mattingly, D.J., Lahr, M.M., Armitage, S., Barton, H., Dore, J.N., Drake, N., Foley, R., Merlo, S., Salem, M., Stock, J. and White, K. 2007. Desert Migrations: people, environment and culture in the Libyan Sahara. Libyan Studies 38: 115-156.

Peregi, Z. 2003. Geological map of Libya 1:250,000, Sheet: Al Haruj al Abyad Ng 33--8; Geological Map Explanatory Booklet.

Thiedig, F.M. and Geyh, M.A. 2004. Zyklische lakustrine Kalke im abflusslosen Murzuq-Becken (Libyen) als Zeugnisse interglazialer Feuchtphasen in Nordafrika während der letzten 500 ka. Beitrag zur Regionalen Geographie 135: 267-288.

Thiedig, F.M., Oezen, D., El-Chair, M. and Geyh, M.A. 2000. The absolute age of the Quaternary lacustrine limestone of the Al Mahruqah Formation - Murzuq Basin, Libya. In: Sola, M.A. and Worsley, D. (eds), Geological Exploration in the Murzuq Basin. Elsevier, Amsterdam: 89-116.

White, K., Charlton, M., Drake, N., McLaren, S., Mattingly, D. and Brooks, N. 2006. Lakes of the Edeyen Awbari and the Wadi al-Hayat. In Mattingly, D., McLaren, S., Savage, E., al-Fasatwi, Y. and Gadgood, K. (eds) The Libyan Desert, Natural Resources and Cultural Heritage. The Society for Libyan Studies, London: 123-130. 